\title{
Implants as drug delivery devices for the treatment of eye diseases
}

\author{
Gisele Rodrigues da Silva ${ }^{1}$, Sílvia Ligório Fialho ${ }^{2}$, Rubens Camargo Siqueira ${ }^{3}$, Rodrigo Jorge ${ }^{4}$, \\ Armando da Silva Cunha Júnior ${ }^{5, *}$
}

\author{
${ }^{1}$ School of Pharmacy, Federal University of São João Del Rei, ${ }^{2}$ Pharmaceutical and Biotechnological Development, \\ Fundação Ezequiel Dias, ${ }^{3}$ Rubens Siqueira Ophthalmic Research Center, ${ }^{4}$ Faculty of Medicine, University of São Paulo at \\ Ribeirão Preto, ${ }^{5}$ Faculty of Pharmacy, Federal University of Minas Gerais
}

\begin{abstract}
The treatment of diseases affecting the posterior segment of the eye is limited by the difficulty in transporting effective doses of drugs to the vitreous, retina, and choroid. Topically applied drugs are poorly absorbed due to the low permeability of the external ocular tissues and tearing. The blood-retina barrier limits drug diffusion from the systemic blood to the posterior segment, thus high doses of drug are needed to maintain therapeutic levels. In addition, systemic side effects are common. Intraocular injections could be an alternative, but the fast flowing blood supply in this region, associated with rapid clearance rates, causes drug concentration to quickly fall below therapeutic levels. To obtain therapeutic levels over longer time periods, polymeric sustained-drug release systems implanted within the vitreous are being studied for the treatment of vitreoretinal disorders. These systems are prepared using different kinds of biodegradable or non-biodegradable polymers. This review aims to demonstrate the main characteristics of these drug delivery implants and their potential for clinical application.
\end{abstract}

Uniterms: Implants/biodegradation. Drugs/delivery systems. Drugs/prolonged delivery systems. Pharmaceutical technology.

\begin{abstract}
O tratamento de doenças do segmento posterior do olho é limitado pela dificuldade no transporte de doses efetivas de fármacos para o vítreo, retina e coróide. Os fármacos aplicados topicamente são pouco absorvidos por causa da baixa permeabilidade dos tecidos oculares externos e ao lacrimejamento. Embora a administração sistêmica seja capaz de transportar fármacos para o segmento posterior do olho, as barreiras hemato-aquosa e hematorretiniana dificultam a absorção e, normalmente, são necessárias doses elevadas, as quais estão geralmente associadas a potenciais efeitos adversos. Injeções intravitreais são capazes de transportar fármacos para o segmento posterior do olho, mas é uma técnica invasiva, pouco tolerada pelos pacientes e apresenta riscos de infecções oculares e danos aos tecidos. Visando a obtenção de níveis terapêuticos adequados de fármacos no segmento posterior do bulbo do olho por longos períodos, sistemas de liberação poliméricos implantados diretamente no vítreo estão sendo investigados para o tratamento de várias doenças vítreo-retinianas. Esses implantes podem ser preparados a partir de diferentes polímeros biocompatíveis, biodegradáveis ou não-biodegradáveis. Nesta revisão, as principais características destes implantes transportadores de fármacos são descritas, expondo suas potencialidades de aplicação clínica.
\end{abstract}

Unitermos: Implantes oculares/biodegradação. Fármacos/sistemas de liberação. Fármacos/ Fármacos/ ação prolongada. Tecnologia farmacêutica.

\section{INTRODUCTION}

In this paper, we present a review on biodegradable and non-biodegradable implants for the treatment of eye

*Correspondence: A. S. Cunha Júnior. Faculdade de Farmácia, Universidade Federal de Minas Gerais. Av. Presidente Antônio Carlos, 6627 - 31270-901 Belo Horizonte - MG, Brasil. E-mail: armando@ufmg.br diseases which includes a discussion of the advantages and disadvantages of each type of implant.

Intraocular implants are controlled drug delivery systems prepared from biodegradable or non-biodegradable polymers. Generally, these are introduced into the vitreous through an incision in the ocular pars plana, which is located posterior to the lens and anterior to the 
retina. Despite the invasive characteristics of the implantation technique, the implants present several advantages that outweigh the inconveniences of the implantation procedure. These advantages include: (1) the overcoming of the blood-retina barrier, allowing drug delivery at therapeutic levels directly into the target site; (2) prolonged drug delivery; and (3) reduction of the side effects frequently observed with intravitreal injections and systemic administration.

\section{NON-BIODEGRADABLE IMPLANTS}

Non-biodegradable polymeric implants can be presented in the form of matrix (monolithic) or reservoir systems. In the matrix system, the drug is dispersed, homogeneously, inside the polymeric matrix or adsorbed onto the surface. Slow diffusion of the drug through the matrix provides its controlled or sustained release. In the reservoir-type system, the drug is surrounded by a permeable non-degradable membrane whose thickness and permeability properties can control the diffusion of the drug into the body. The release kinetics of the drug from this system suggest that if the concentration of the drug within the reservoir is in constant equilibrium with the inner surface of the enclosed membrane, the driving force for diffusional release of the agent is constant, and zero order release kinetics of the drug from the delivery system is achieved. The drug-release rate is determined by different factors, such as the release area, the thickness of the polymeric membrane, the implant form, as well as drug solubility (Bourges et al., 2006).

The polymers most employed in the preparation of these implants include: silicon, polyvinyl alcohol (PVA) and ethylene vinyl acetate (EVA). Polymers, such as silicon and PVA, are easily permeable for a variety of lipophilic drugs due to their hydrophobic characteristics. EVA is impermeable to most drugs and is used as a membrane around the reservoir to reduce the rate of drug diffusion through the implant (Smith et al., 1992; Dash, Cudworth, 1998; Yasukawa et al., 2004; Bourges et al., 2006).

\section{Non-biodegradable implants in the treatment of cytomegalovirus retinitis}

Cytomegalovirus retinitis (CMV) is the major ocular infection in acquired immune deficiency syndrome (AIDS) patients. Several studies have been carried out in an attempt to develop non-biodegradable intraocular implants containing ganciclovir for the treatment of cytomegalovirus retinitis (Ashton et al., 1992; Martin et al., 1994 Sanborn et al., 1992; Charles, Steiner, 1996). These studies were performed on animals and humans and, in 1996, led to the development of Vitrasert ${ }^{\circledR}$ (Bausch \& Lomb, USA) and its approval by the Food and Drug Administration (FDA) (Bourges et al., 2006).

Vitrasert ${ }^{\circledR}$ is a controlled-release intraocular implant that contains $4.5 \mathrm{mg}$ of ganciclovir. This non-biodegradable implant is composed of a ganciclovir tablet surrounded by PVA/EVA. Vitrasert ${ }^{\oplus}$ was developed before the evolution of antiretroviral therapy, when patient life expectancy was approximately 12 months. Consequently, this precluded proper evaluation of possible complications that may stem from the use of the implant beyond this 12-month period. With the introduction of antiretroviral therapy, AIDS patient life expectancy increased significantly, and the treatment of CMV retinitis, as well as the complications associated with the use of the implant and the surgical procedure could be assessed over a longer period of time. Among the described complications, vitreous hemorrhage was the most common in both the implantation procedure and implant removal. Some complications, possibly related to the implant, were also reported, including: cataract, retinal detachment, vitreous hemorrhage, hypotony, epiretinal membrane, macular edema, and endophthalmitis. These complications were observed during the first two years of implantation in a way that suggested their incidence was associated with several factors and not only with the presence of the implant. Briefly, the results of this research, carried out between 1995 and 2001, suggested that the complications directly related to the implantation procedure or to the presence of the implant in the eye, are not very common but can occur within a 7-year period, thus indicating the need to carefully select cases in which the implant should be used. It was also observed that the continuous use of the implant associated with the antiretroviral therapy could in fact reduce vision loss, as it was able to treat CMV retinitis (Kapel et al., 2006).

\section{Non-biodegradable implants in the treatment of uveitis}

Uveitis is originally used to describe ocular inflammation of the uvea, though it can also be used to describe inflammations in the retina, the optical nerve, and the vitreous (Herrero-Vanrell, Refojo, 2001). The treatment of infectious or non-infectious uveitis requires pharmacological therapy with steroids, immunosuppressives, antibiotics, or all these drugs combined, to suppress chronic inflammatory processes or, in specific cases, to prevent recurrence (Yasukawa et al., 2004). These uveal inflammations can reduce visual acuity and promote vision loss. The potential of intraocular implants with controlled drug release to reduce these effects has been evaluated. 
Retisert $^{\circledR}$ is an intraocular implant that contains fluocinolone acetonide (FA), developed and commercialized by Bausch \& Lomb, to treat non-infectious uveitis, which affects the posterior segment of the eye. Retisert ${ }^{\circledR}$ is composed of an FA tablet containing microcrystalline cellulose, magnesium stearate, and PVA (Figure 1). This tablet presents a silicone elastomer coating containing a release orifice. A semi-permeable layer of PVA is positioned between the tablet and the release orifice to create a drug release diffusion barrier. Clinical studies carried out on patients with severe non-infectious uveitis demonstrated the efficacy of Retisert ${ }^{\circledR}$, where the FA released over a period of approximately 30 months significantly reduced the recurrence of the disease, increased visual acuity and reduced the need of supplementary topical, systemic, and periocular therapies. Progression of cataract and increase in intraocular pressure (IOP) were the main side effects related to the use of Retisert ${ }^{\circledR}$ (Jaffe et al., 2006).

Studies carried out by Debra and coworkers showed that the incidence and magnitude of the increase in IOP were significant in the eyes receiving the implant, which required subsequent pharmacological treatment or surgical procedures to reduce the IOP (Debra et al., 2007). Therefore, patients must be aware of the possibility of an increase in IOP and must be prepared for the constant monitoring of IOP as well as for the significant risks of developing glaucoma.

Other studies have been carried out in an attempt to develop intraocular non-biodegradable devices for the controlled release of drugs to treat non-infectious uveitis. These studies are described below.

Cheng et al. prepared non-biodegradable implants for the sustained release of dexamethasone for the treatment of experimental uveitis in rabbit eyes (Cheng et al., 1995). These implants were effective in suppressing induced inflammation and released the drug for approximately 105 days.

Jaffe et al. developed PVA/EVA implants for the intravitreal administration of cyclosporin A (CsA) for the treatment of experimental uveitis in rabbit eyes (Jaffe et al., 1998). The histology showed that the untreated eyes presented exacerbated inflammation and a disarrangement of retinal cell layers, while the eyes that received the implants containing CsA presented a significant decrease in inflammation and preserved retinal structure. Furthermore, the implants released the drug at therapeutic levels for at least 6 months with no detection of the drug in the blood stream.

Okabe and coworkers developed PVA/EVA implants for intrascleral application and the controlled release of betamethasone (Okabe et al., 2003). The implants released the drug for 4 weeks with no significant toxic reactions observed in electroretinographic evaluations or histological studies carried out on rabbit eyes. These results suggest that the intrascleral route can also be used for the implantation of the controlled release of drugs for the treatment of posterior uveitis.

\section{Non-biodegradable implants in the treatment of diabetic retinopathy}

Diabetic retinopathy is the second most prevalent cause of blindness in adults in the western world, representing approximately $19 \%$ of blindness cases. Diabetic maculopathy, in which macular edema is the main sign, is the most frequent cause of significant visual loss in diabetics, with a prevalence of $18 \%$ to $20 \%$ in type I and type II diabetics, respectively. The visual loss promoted

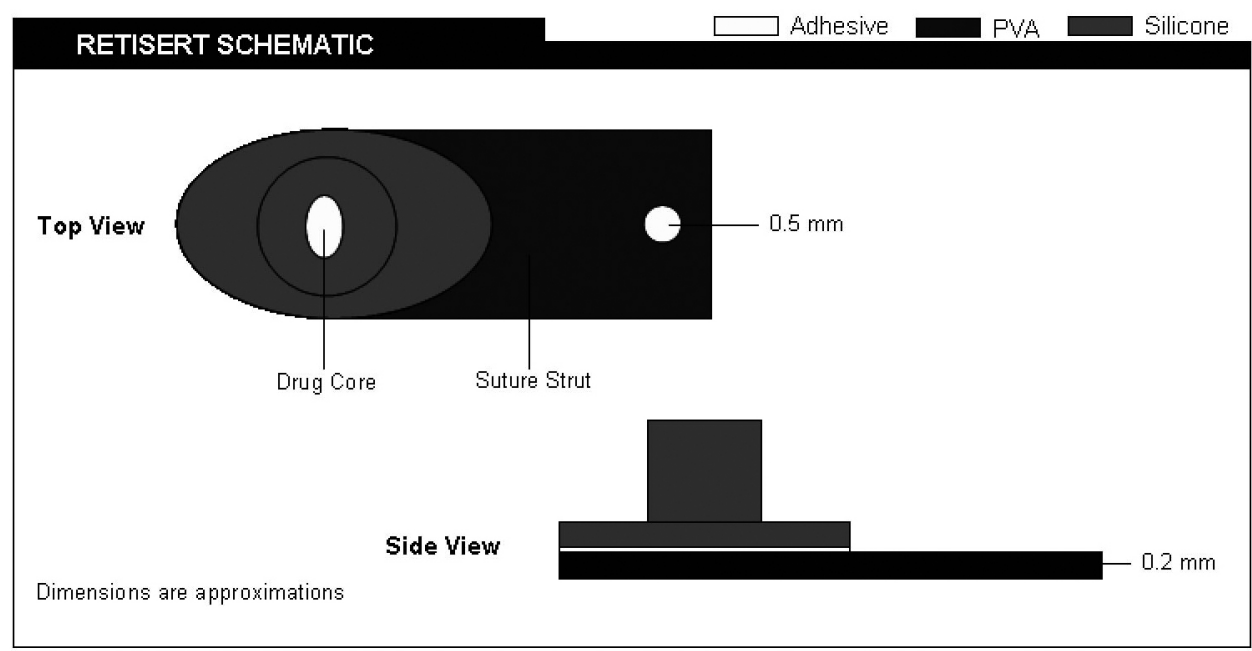

FIGURE 1 - Schematic representation of Retisert ${ }^{\circledR}$ (http://www.retisert.com/professional_delivery.html). 
by diabetes can be avoided or reduced with appropriate clinical control as well as through use of local and systemic treatments. In diabetic retinopathy, the rupture of the retinal-blood barrier allows the release of liquids and plasmatic components (mainly lipoproteins) into the interstitial space of the retina, leading to the formation of edemas. Edemas can be focal or diffuse and appear clinically as a thick and opacified retina (Motta et al., 2008).

The treatment of diabetic retinopathy and, consequently, of diabetic macular edema, should be performed using different approaches aimed at prevention, intervention, and restoration. In preventive treatment, hypoglycemic and antihypertensive drugs should be used whilst intravitreal steroids and anti-angiogenic and antiproliferative drugs should be used for interventions. Finally, restorations require surgical procedures (Ávila, 2003).

Non-biodegradable implants containing fluocinolone acetonide for the treatment of diabetic macular edema are being assessed in phase III clinical studies. These implants, called Iluvien ${ }^{\circledast}$ (Alimera Sciences Products), are small tubes measuring $3.5 \mathrm{~mm}$ in length and $0.37 \mathrm{~mm}$ in diameter which can be inserted into the vitreous by injection and need no surgical procedures. They can promote controlled release of fluocinolone acetonide for 24 to 36 months (Kane et al., 2008).

\section{Non-biodegradable implants containing cells in the treatment of retinal diseases}

Recently, MacDonald et al. (2007) demonstrated a new therapeutic approach for the treatment of retinal diseases in humans (phase I clinical studies). This approach involves a non-biodegradable intraocular implant containing encapsulated cells that are able to produce ciliary neurotrophic factor (CNTF). CNTF is a member of the interleukin- 6 family of proteins which acts by binding a receptor complex consisting of the CNTF receptor alpha (CNTFR- $\alpha$ ) and two others receptors. CNTFR- $\alpha$ has been localized in retinal pigment epithelial cells, rods and cones, inner nuclear cells, as well as retinal ganglion cells and their axons. When bound to its receptor complex, CNTF activates the extracellular signal-regulated kinase pathway, present in both rods and cones, thus inducing neuroprotection. Patients with retinitis pigmentosa who received these intravitreal implants presented an improvement in visual acuity. Furthermore, the implants did not produce side effects, such as increased IOP, retinal detachment, infection, or severe inflammation. Moreover, the implant cells released CNTF at therapeutic levels for 6 months. The results from this research call for further phase II and phase III clinical studies to investigate whether or not CNTF can stabilize or improve visual functions.

\section{BIODEGRADABLE IMPLANTS}

The implants containing biodegradable polymers can also be of two types: matricial (monolithic) and reservoir systems. In the matricial system, the polymer degrades slowly under physiological conditions, and the drug is released during polymer degradation. In this case, the drug can also be released by diffusion through the matrix pores. In reservoir systems, the membrane generally degrades slower than in drug diffusion (Dash, Cudworth, 1998; Fialho et al., 2003).

A wide variety of natural and synthetic biodegradable polymers have been investigated for the development of implants. Natural polymers, such as bovine serum albumin, human serum albumin, collagen, and gelatin have been studied for drug delivery. However, the use of these polymers is limited due to their higher cost and questionable purity. Synthetic polymers, such as poly(amides), poly(amino acids), poly(alkyl- $\alpha$-cyano acrylates), poly(esters), poly(orthoesters), poly(urethanes), and poly(acrylamides) have been increasingly used to deliver drugs as they are devoid of most of the problems associated with natural polymers (Jain, 2000). Of this group of polymers, the thermoplastic aliphatic poly(esters) such as PLA, PGA, and especially PLGA, have been the most studied. The polymers and copolymers derived from the lactide and glycolide acids (PGA, PLA, and PLGA) are aliphatic polyesters that can be degraded by enzymatic or non-enzymatic hydrolysis. The ester bonds of these polymers are susceptible to hydrolytic degradation under physiological conditions. In addition, the degradation products formed (lactic and glycolic acids) are metabolized into carbon dioxide and water through the Krebs cycle (Chandra, Rustgi, 1998; Yasukawa et al., 2005).

Poly( $\varepsilon$-caprolactone) (PLC) is a semi-crystalline and hydrophobic polyester, formed from the polymerization of $\varepsilon$-caprolactone monomers. PCL degrades through hydrolysis due to ester bonds. However, the degradation rate of PCL is slow (2 to 3 years) (Bourges et al., 2006; Nair, Laurencin, 2007). The slow degradation, high biocompatibility, and high permeability of drugs are characteristics of PCL that have been investigated to develop controlled drug delivery devices in the eye (Kimura, Ogura, 2001; Dong et al., 2006; Peyman, Ganiban, 2006; Fialho et al., 2008).

Poly(ortho esters) (POE) are hydrophobic biodegradable polymers specially developed for controlled drug release. Since 1970, four families of POE have been investigated in biomedical applications. POE I and POE II 
families are not currently used in ophthalmology. POE III presents polymeric, highly flexible chains that form a gel at room temperature. The viscous nature of this polymer allows the incorporation of therapeutic substances without the use of organic solvents. Moreover, POE III can be injected directly into the eye using appropriate needles (Bourges et al., 2006; Nair, Laurencin, 2007). The intracameral and intravitreal biocompatibility of POE II has been extensively investigated. Intracameral biocompatibility was found to be dependent on the amount of polymer injected into the anterior chamber. When $50 \mu \mathrm{L}$ was administered, the polymer degraded in two weeks. The clinical results also demonstrated good biocompatibility of POE III, with no toxicity of the ocular tissues or increase in IOP. The injection of greater volumes proved to be inappropriate as the direct contact of the material with the corneal endothelium caused a reversible edema and inflammation in the anterior chamber, which reduced after several days. The intravitreal administration of POE III was well tolerated where the polymer degraded slowly in the vitreous and no inflammatory process occurred (Einmahl et al., 2000). POE IV presented significant degradation due to the incorporation of lactide and glycolide acids in the polymeric matrix. The degradation rate can vary from days to months depending on the proportion of the acids incorporated. Studies carried out by Einmahl and coworkers demonstrated the biocompatibility of POE IV after subconjunctival injection, with complete degradation of the polymer within approximately 5 weeks (Einmahl et al., 2002; Einmahl et al., 2003). After intravitreal and suprachoroidal injection, the polymer degraded in approximately 3 and 6 months, respectively, and the biocompatibility was excellent with no inflammatory reactions. Despite the advantageous characteristics of POE III and IV in ocular applications, the difficulty in producing polymers on an industrial scale limits their use.

\section{Biodegradable implants in the treatment of cytomegalovirus retinitis}

Kunou and coworkers (1995) developed biodegradable implants made from PLGA (75:25) and 25\% of ganciclovir for the treatment of CMV retinitis. These implants presented a triphasic drug release profile. In the first phase, approximately $40 \%$ of the drug was released within one week. In the diffusional phase, about $10 \%$ of ganciclovir was released in 8 weeks, whereas in the final phase, approximately $100 \%$ of the drug was released within 4 weeks. Due to the non-enzymatic hydrolysis of PLGA, the implant completely disappeared after 5 months.

The main disadvantages of implants prepared with lactide and glycolide acids copolymers include: 1) the release of large amounts of the drug (overdose) in the final phase and 2) the difficulty of prolonging and increasing drug release rates in the diffusional phase. To reduce these complications, Kunou and coworkers developed implants containing PLA blends with different molecular weights (70-kDa and 50-kDa), at the proportion of 80:20 (Kunou et al., 2000). These systems promoted a more homogeneous release of ganciclovir in the final phase and presented a high rate of drug release in the diffusional phase over a prolonged period (longer than 25 weeks).

\section{Biodegradable implants in the treatment of uveitis}

Dong et al. (2006) developed implants containing CsA and the glycolide-co-lactide-co-caprolactone copolymer (PGLC) for the treatment of experimental chronic uveitis in rabbit eyes. The results demonstrated that inflammation in eyes with no treatment, non-medicated implant, and oral CsA was more severe than in those with CsAPGLC DDS at all time points. One group with oral CsA administration was intentionally included in this study to compare the drug toxicity with the CsA-PGLC implant group. The animals that received oral CsA presented severe renal and hepatic insults, which were not observed in the other groups. The concentration of CsA released in the eyes from the implants was within the therapeutic range to suppress inflammation, and no intraocular toxicity was evident in the ocular tissues.

Posurdex ${ }^{\circledR}$ (Allergan, USA) is an intravitreal biodegradable implant that contains PLGA and dexamethasone and is currently undergoing phase III clinical trials. This controlled delivery system has been designed for the treatment of macular edemas secondary to retinal vein occlusion, diabetic macular edema, uveitis, and IrvineGass syndrome (Amo, Urtti, 2008/). Kuppermann and coworkers (2007) evaluated the efficacy and safety of Posurde ${ }^{\circledR}$ containing 350 and $700 \mu \mathrm{g}$ of dexamethasone over a 6-month period in 315 patients who presented persistent macular edema for at least 90 days. The results showed that after 3 months of treatment, $35 \%$ and $24 \%$ of the patients who received $700 \mu \mathrm{g}$ and $350 \mu \mathrm{g}$ of dexamethasone, respectively, presented an improvement in visual acuity. It could therefore be concluded that Posurdex ${ }^{\circledR}$ with a higher dose of dexamethasone is more effective in treating persistent macular edemas. According to the results, depending on the time required for the treatment, Posurdex ${ }^{\circledR}$ may be a good option for the management of uveitis (Amo, Urtti, 2008).

Recently, Fialho and coworkers developed biodegradable implants containing PLGA and $1000 \mu \mathrm{g}$ of dexamethsone for the treatment of inflammatory diseases in the 
posterior segment of the eye (Fialho, Silva-Cunha, 2005; Fialho et al., 2006). The developed implants were inserted into the vitreous of rabbits through pars plana. In vivo studies showed that the intravitreous drug concentration remained within the therapeutic range during the 8-week evaluation period. The system studied was not toxic to the normal rabbit retina, and no significant increase in intraocular pressure was observed. The satisfactory results and the similarity between these implants and Posurdex call for further studies regarding the clinical application of these systems.

In a bid to obtain systems that were more easily implanted in the eyes without the need for surgical procedures, Fialho and coworkers developed biodegradable implants similar to those described in the previous paragraph (Fialho et al., 2007), but measuring $8.0 \pm 0.3 \mathrm{~mm}$ in length and $0.40 \pm 0.03 \mathrm{~mm}$ in diameter (Figure 2). These systems were implanted into rabbit eyes through a 25 -Gauge transcleral cannula trocar and released dexamethasone in the vitreous within the therapeutic range for more than 3 weeks. These systems were not associated with retinal histological changes or elevated intraocular pressure in normal rabbit eyes.

Fialho et al. also developed poly-e-caprolactone (PCL) implants containing dexamethasone (Fialho et al., 2008; Fialho et al., 2009). These implants released dexamethasone concentrations in vitro, indicating their potential for suppressing several inflammatory processes. Furthermore, the systems were well tolerated after 30 days of implantation in rabbit eyes, evidenced absence of signs of inflammatory cells in the vitreous or anterior chamber. In the in vivo study, the drug was released within the therapeutic range for 55 weeks after the implantation of the system in rabbit eyes.

Kim and coworkers (2008) developed implants containing PLA and triamcinolone acetonide (TA). In vivo release of the drug was measured in aqueous humor, vitreous, and retina-choroid at 1,2, 4, 8, and 12 weeks after intrascleral implantation. TA was detected in aqueous humor up to 4 weeks, and in retina-choroid up to 8 weeks, after implantation but was detected constantly over 12 weeks in the vitreous. The possible reason for these findings, where the drug was detected for a longer period in the vitreous than in the retina, choroids, and aqueous humor, may be related to the drug clearance via choroidal blood vessels.

\section{Biodegradable implants in the treatment of proliferative vitreoretinopathy}

Proliferative vitreoretinopathy (PVR) is the process in which migration and proliferation of cells occurs in the subretinal space, vitreous and retina. PVR involving the formation of fibrous membranes, composed of retinal pigment epithelial cells, glial cells, macrophages, and fibroblasts. Contractile forces generated within the fibrous tissue formed ultimately lead to retinal detachment and consequent vision loss (Yasukawa et al., 2004). It is believed that PVR can be inhibited, thus simultaneously preventing the course of the disease, which comprises three phases: inflammation, cellular proliferation, and healing, leading to retinal traction.

Several studies have reported on the treatment of experimental PVR in rabbit eyes, focusing on the use of intraocular devices containing different antimetabolites that are able to inhibit the cellular proliferation mechanism. Dong et al. developed PLGA implants containing 420, 650, and $1040 \mu \mathrm{g}$ of all-trans retinoic acid (ar-RA) (Dong et al., 2006). The implants with the lower concentration of atRA failed to inhibit PVR. On the other hand, the implants with the higher doses of at-RA presented a satisfactory

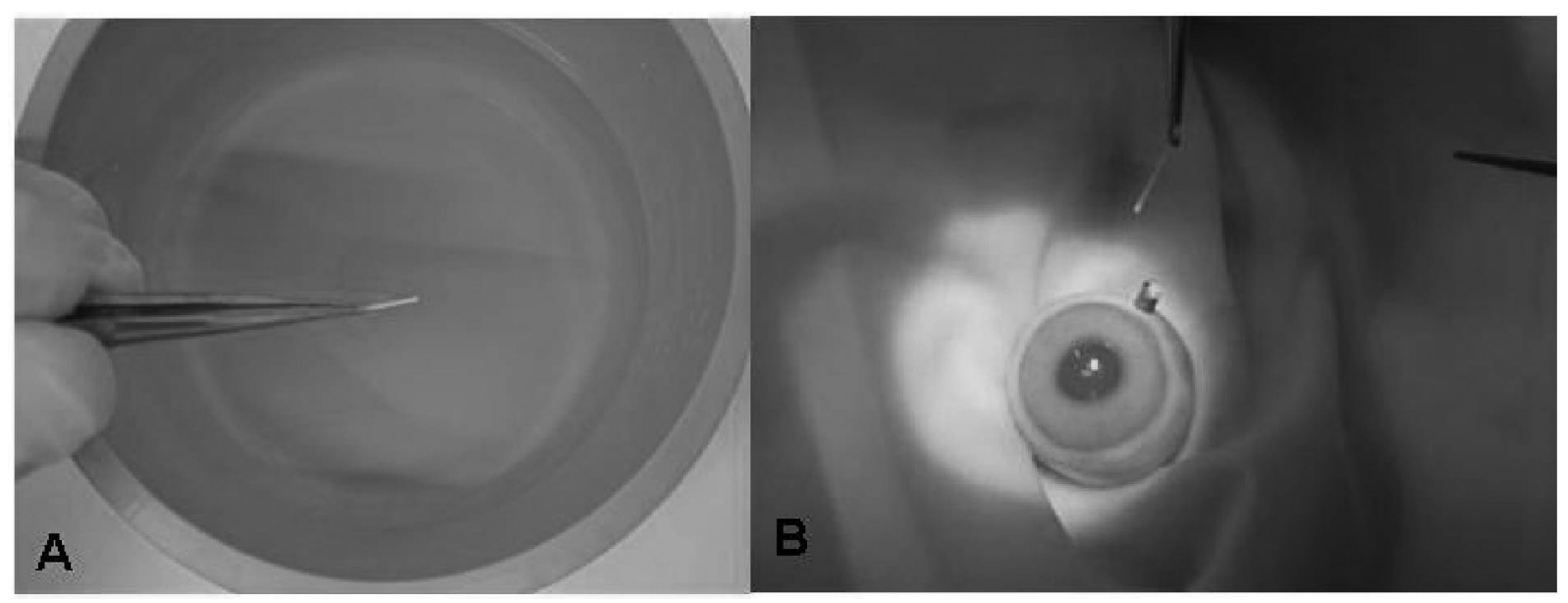

FIGURE 2 - Photography of the biodegradable device that does not require surgical procedure before (A) and after (B) implantation 
antiproliferative effect and released the antimetabolite for 8 weeks. Nevertheless, despite the inhibition of PVR, the release profile of at-RA did not coincide with the cellular proliferation pattern.

Rubsamen and coworkers prepared PLGA implants containing 5-fluorouracil (5-FU) which provided drug release within the therapeutic range for 14 days (Rubsamen et al., 1994). The retina of eight of the nine rabbits that received the polymer with 5-FU, compared to the animal that received the control polymer without the drug, remained attached. No evidence of toxic effects of the drug or polymer implant was observed on electroretinographic and histopathological studies.

Yasukawa and coworkers (2002) developed implants from blends of PLGA and different concentrations of cis-hydroxyproline (CHP). Implants loaded with 20\% and $15 \%$ CHP and made from PLGA (copolymer ratios $65 / 35$ and 50/50; mean molecular weights of 103000 and 93000 , respectively) were chosen for implantation, based on their in vitro release profile. These implants proved to be effective in the treatment only during the first week because the release rate of the drug and length of the diffusional phase were not satisfactory. Therefore, to overcome these problems, two implants (one of PLGA 65:35 and the other of PLGA 50:50) were inserted simultaneously into rabbit eyes, reducing the incidence of retinal detachment from $89 \%$ to $57 \% 28$ days after implantation. The reduction of the incidence of retinal detachment was similar to that observed when $20 \mu \mathrm{g}$ of CHP was directly injected into eyes with induced PVR. Implantation with two PLGA 50:50 implants had no significant effect on PVR. The results suggest that the combined release profiles of different implants are more effective in reducing retinal detachment in eyes with induced PVR.

POE IV implants (molecular weight $=6900)$ containing 5-FU or dexamethasone or 5-FU associated with dexamethasone, were developed in an attempt to prevent experimental PVR in rabbit eyes. The induced PVR was clinically classified as follows: grade 0 : No PVR; grade 1: epiretinal membranes; grade 2: focal traction, vessel abnormalities, and tortuosity; grade 3: localized retinal detachment; grade 4: extended retinal detachment and peripapillary detachment; and grade 5: total retinal detachment, fixed folds, and retinal tears. The implants containing POE IV alone did not affect the development of PVRs graded with scores of 4 and 5. On the other hand, PVR grades 2 to 3 were observed in eyes treated with POE containing either $1 \%$ of $5-\mathrm{FU}$ or $1 \%$ of dexamethasone. Eyes treated with POE releasing both drugs showed the lowest PVR grade $(1 \pm 0.5)$, thus demonstrating that the combination of the two drugs in POE IV implants was more effective in the treatment (Bourges et al., 2006).

Zhou and coworkers (1998) developed PLGA implants containing three drugs: 5-fluorouracil (5-FU, an antimetabolite), triamcinolone (Triam, a corticosteroid), and human recombinant tissue plasminogen activator $(\mathrm{t}$ PA, a thrombolytic agent). These drugs prevented PVR by three separate mechanisms: (i) inhibiting cellular proliferation, (ii) inhibiting the inflammatory response, and (iii) inhibiting fibrin matrix formation. In vitro release studies showed that 5-FU and Triam were released at a rate of $1 \mu \mathrm{g}$ /day over a 4-week period and 10 to $190 \mu \mathrm{g} /$ day over a 2-week period, respectively. After a time lag of 2 days, t-PA was released at a rate of 0.2 to $0.5 \mu \mathrm{g}$ /day over a 2-week period. Despite the promising results, these multiple-drug delivery implants require further study before clinical application.

Some studies were carried out using intraocular implants containing only one antiproliferative drug, while other studies used implants containing two or more drugs. The administration of multiple drugs can potentially improve the treatment of PVR as the processes of cellular proliferation, cellular migration, and membrane synthesis can be targeted simultaneously.

\section{Biodegradable implants in the prevention of post- cataract surgery diseases}

The inconvenience related to cataract surgery, such as inflammations and infections, if untreated or treated late, can prolong patient discomfort and contribute to the occurrence of complications, such as macular edema and posterior capsular opacification. Prevention has been performed with the use of eyedrops containing anti-inflammatory and antibiotic drugs. However, drug delivery systems are being developed to avoid the use of eyedrops and make cataract surgery safer.

Surodex (Oculex Pharmaceuticals, Sunnyvale, California) is a monolithic system containing PLGA and $60 \mu \mathrm{g}$ of homogeneously dispersed dexamethasone. This biodegradable system is used to avoid inflammation after cataract surgery. Initially, it was demonstrated that this system, implanted in the anterior chamber of rabbit eyes, provided controlled release of dexamethasone in zero order kinetics over a 7-day period. The safety of this implant was demonstrated in phase I toxicological studies (FDA protocol $\mathrm{n}^{\circ}$ 94001). Studies in humans were later carried out to compare the performance of Surodex against eyedrops containing $0.1 \%$ of dexamethasone, in the eyes of patients who had undergone cataract surgery and received intraocular lens (IOL). The results showed that Surodex ${ }^{\circledR}$ was more 


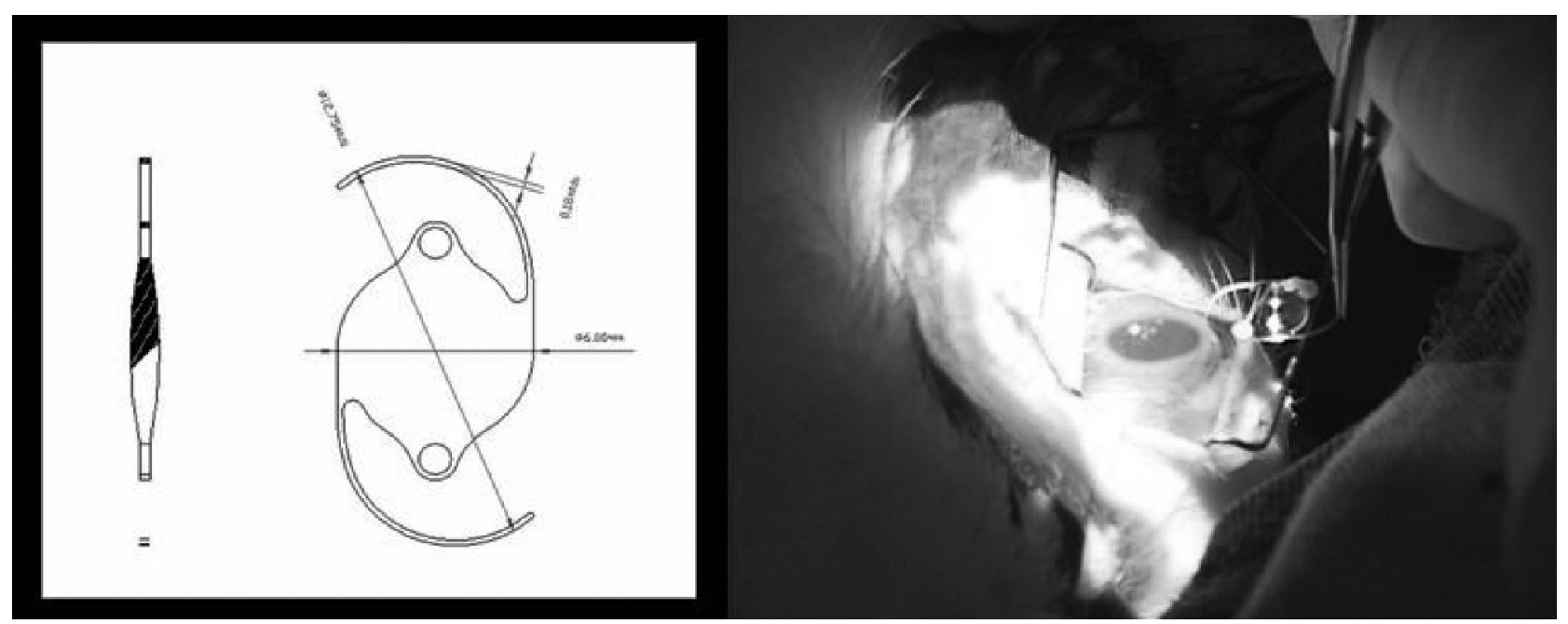

FIGURE 3 - Schematic representation of IOL containing the rings for implant insertion (A) and photography showing the implantation of the IOL containing the biodegradable implant (B).

effective in reducing post-surgical inflammation (Tan et al., 1999). Wadood and coworkers also evaluated the safety and efficacy of Surodex ${ }^{\circledR}$ versus $0.1 \%$ dexamethasone eyedrops in patients with inflammation after cataract surgery (Wadood et al., 2004). Once again, Surodex ${ }^{\circledR}$ proved to be more effective in controlling intraocular inflammation. Therefore, according to these studies, there are three main advantages of implants placed in the anterior chamber, as compared to eyedrops: (1) a smaller amount of drug used in the formulation and consequent reduction of adverse effects and systemic toxicity; (2) the control of drug release in the anterior segment with zero order kinetics; and (3) the reduction of complications in patients who use eyedrops incorrectly due to low compliance with the therapy. Surodex ${ }^{\circledast}$ is currently undergoing phase III clinical studies (Seah et al., 2005).

In another study conducted by Siqueira et al. (2006), a delivery system attached to an IOL made of poly (methylmetacrylate) (PMMA) was prepared. The developed lens was biconvex, with an optical diameter of $6 \mathrm{~mm}$, total diameter of $12.75 \mathrm{~mm}, \AA$ constant of 118.5 , "C" modified loops and refraction index of 1.492. At the loops insertion, a ring of $1 \mathrm{~mm}$ in diameter was made using the same material, and the dexamethasone delivery systems were attached to the lens' rings. The IOL were implanted in rabbit eyes. The results of this study showed that the IOL containing biodegradable devices promoted an appropriate and controlled release of dexamethasone. After 6 days of implantation, approximately $1.0 \mathrm{mg} / \mathrm{mL}$ and $0.4 \mathrm{mg} / \mathrm{mL}$ of the drug were released into the aqueous humor and the vitreous, respectively. These values are higher than those observed in other studies, in which dexamethasone delivery systems were implanted into the anterior chamber after cataract surgery. Studies aimed at developing folda- ble IOL containing the drug delivery system are currently underway.

\section{CONCLUSIONS}

Non-biodegradable intraocular implants present the advantage of controlling drug release with predicted kinetics over a long period of time. Furthermore, elevated concentrations of the drug can be found in the vitreous, while small concentrations are detected in the aqueous humor and blood. However, in contrast to biodegradable implants, these devices must be removed after complete drug release, representing a risk for patients and a disadvantage of the systems.

Biodegradable implants do not have to be removed as they are degraded and absorbed or eliminated from the body. This reduces the need for further surgery to remove implants after complete drug release, and can increase patient compliance with the treatment. However, the development of these systems is more complicated when compared to non-biodegradable systems as some key variables, such as the degradation kinetics of the polymer in vivo, must be considered.

Finally, there are many challenges to consider and overcome in order to develop biodegradable implants able to provide prolonged drug release within the therapeutic range for effective treatment of ocular diseases.

\section{REFERENCES}

AMO, E.M.; URTTI, A. Current and future ophthalmic drug delivery systems: A shift to the posterior segment. Drug Discov. Today, v.13, p.135-143, 2008. 
ASHTON, P.; BROWN, J.D., PEARSON, P.A., BLANDFORD, D.L., SMITH, T.J., ANAND, R., NIGHTINGALE, S.D., SANBORN, G.E. Intravitreal ganciclovir pharmacokinetics in rabbits and man. J. Ocul. Pharmacol., v.8, p.343-347, 1992.

ÁVILA, M.A. Retina no Século XXI. Arq. Bras. Oftalmol., v.66, p.719-730, 2003.

BOURGES, J.L.; BLOQUEL, C.; THOMAS, A.; FROUSSART, F.; BOCHOT, A.; AZAN, F.; GURNY, R.; BENEZRA, D.; BEHAR-COHEN, F. Intra-ocular implants for extended drug delivery: Therapeutic applications. Adv. Drug Deliv. Rev., v.58, p.1182-1202, 2006.

CHANDRA, R.; RUSTGI, R. Biodegradable polymers. Prog. Polym. Sci., v.23, p.1273-1235, 1998.

CHARLES, N.C.; STEINER, G.C. Ganciclovir intra-ocular implant. A clinicopathologic study. Ophthalmolog., v.103, p.416-421, 1996.

CHENG, C-K.; BERGER, A.S.; PEARSON, P.A.; ASHTON, P.; JAFFE, G.J. Intravitreal sustained-release dexamethasone device in the treatment of experimental Uveitis. Invest. Ophthalmol. Vis. Sci., v.36, p.442-453, 1995.

DASH, A.K.; CUDWORTH II, G.C. Therapeutic application of implantable drug delivery systems. J. Pharmacol. Toxicol. Methods, v.10, p.1-12, 1998.

DEBRA, A.G.; DAVID, G.G.; ANTHONY, H.; DAVID, G.C.; GLENN, J.J.; PEARSON, P.A.; DALE, W.U.; TIMOTHY, L.C. Intra-ocular pressure in patients with uveitis treated with fluocinolone acetonide implants. Arch. Ophthalmol., v.125, p.1478-1485, 2007.

DONG, X.; CHEN, N.; XIE, L.; WANG, S. Prevention of experimental proliferative vitreoretinopathy with a biodegradable intravitreal drug deliver system of all-trans retinoic acid. Retina, v.26, p.210-213, 2006.

EINMAHL, S.; BEHAN-COHEN, F.; TABATABAY, C.; D'HERMIES, F.; HELLER, J.; GURNY, R. A viscous bioerodible poly(ortho ester) as a new biomaterial for intraocular application. J. Biomed. Mater. Res., v.50, p.566-573, 2000.
EINMAHL, S.; PONSART, S.; BEJJANI, R.A.; D'HERMIES, F.; SAVOLDELLI, M.; HELLER, J.; TABATABAY, C.; GURNY, R.; BEHAN-COHEN, F. Ocular biocompatibility of a poly(ortho ester) characterized by autocatalyzed degradation. J. Biomed. Mater. Res., v.67, p.44-53, 2003.

EINMAHL, S.; SAVOLDELLI, M.; D’HERMIES, F.; TABATABAY, C.; GURNY, R.; BEHAN-COHEN, F. Evaluation of a novel biomaterial in the suprachoroidal space of the rabbit eye. Invest. Ophthalmol. Vis. Sci., v.43, p.1533-1539, 2002.

FIALHO, S.L.; REGO, M.G.B.; CARDILLO, J.A.; SIQUEIRA, R.C.; JORGE, R.; SILVA-CUNHA, A. Implantes biodegradáveis destinados à administração intra-ocular. Arq. Bras. Oftalmol., v.66, p.891-896, 2003.

FIALHO, S.L.; SILVA-CUNHA, A. Manufacturing techniques of biodegradable implants intended to intraocular application. Drug Deliv., v.12, p.109-116, 2005.

FIALHO, S.L.; JORGE, R.; SIQUEIRA, R.C.; SILVA-CUNHA, A. Biodegradable implants for ocular delivery of antiinflammatory drugs. J. Drug Del. Sci. Technol., v.17, p.9397, 2007.

FIALHO, S.L.; BEHAR-COHEN, F.; SILVA-CUNHA, A. Dexamethasone-loaded poly( $\varepsilon$-caprolactone) intravitreal implants: A pilot study. Eur. J. Pharm. Biopharm., v.68, p.637-646, 2008.

FIALHO, S.L.; REGO, M.G.B.; SIQUEIRA, R.C.; JORGE, R.; HADDAD, A.; RODRIGUES-JUNIOR, A.L.; MAIA-FILHO, A.; SILVA-CUNHA, A. Safety and pharmacokinetics of an intravitreal biodegradable implant of dexamethasone acetate in rabbit eyes. Curr. Eye. Res., v.31, p.525-534, 2006.

HERRERO-VANRELL, R.; REFOJO, M.F. Biodegradable microspheres for vitreoretinal drug delivery. Adv. Drug Deliv. Rev., v.52, p.5-16, 2001.

JAFFE, G.J.; MARTIN, D.; CALLANAN, D.; PEARSON, P.A.; LEVY, B.; COMSTOCK, T. Fluocinolone acetonide implant (Retisert) for noninfectious posterior uveitis: thirtyfour-week results of a multicenter randomized clinical study. Ophthalmology, v.113, p.1020-1027, 2006. 
JAFFE, G.J.; YANG, C-S.; WANG, X-C.; COUSINS, S.W.; GALLEMORE, R.P.; ASHTON, P. Intravitreal sustainedrelease cyclosporine in the treatment of experimental uveitis. Ophthalmology., v.105, p.46-56, 1998.

JAIN, R. A. The manufacturing techniques of various drug loaded biodegradable poly(lactide-co-glycolide) (PLGA) devices. Biomaterials, v.21, p.2475-2490, 2000.

KANE, F.E.; BURDAN, J.; CUTINO, A.; GREEN, K.E. Iluvien: a new sustained delivery technology for posterior eye diseases. Expert. Opin. Drug Deliv., v.5, p.1039-1046, 2008

KAPEL, P.J.; CHARONIS, A.C.; HOLLAND, G.N.; NARAYANAN, R.; KULKARNI, A.D.; YU, F.; BOYER, D.S.; ENGSTROM, R.E.; KUPPERMANN, B.D. Outcomes associated with ganciclovir implants in patients with SIDArelated cytomegalovirus retinitis. Ophthalmology, v.113, p.673-683, 2006.

KIM, Y-M.; LIM, J-O.; KIM, H-K.; KIM, S-L.; SHIN, J-P. A novel design of one-side coated biodegradable intrascleral implant for the sustained release of triamcinolone acetonide. Eur. J. Pharm. Biopharm., v.70, p.179-186, 2008.

KIMURA, H.; OGURA, Y. Biodegradable polymers for ocular drugs delivery. Ophthalmologica., v.215, p.143-155, 2001.

KUNOU, N.; OGURA, Y.; HASHIZOE, M.; HONDA, Y.; HYON, S.; IKADA, Y. Controlled intra-ocular delivery of ganciclovir with use of biodegradable scleral implant in rabbits. J. Control. Release., v.37, p.143-150, 1995.

KUNOU, N.; OGURA, Y.; YASUKAWA, T.; KIMURA, H.; MIYAMOTO, H.; HONDA, Y.; IKADA, Y. Long-term sustained release of ganciclovir from biodegradable scleral implant for the treatment of cytomegalovirus retinitis. $J$. Control. Release., v.68, p.263-271, 2000.

KUPPERMANN, B.D.; BLUMENKRANZ, M.S.; HALLER, J.A.; WILLIAMS, G.A.; WEINBERG, D.V.; CHOU, C.; WHITCUP, S.M. Randomized controlled study of an intravitreous dexamethasone drug delivery system in patients with persistent macular edema. Arch. Ophthalmol., v.25, p.309-317, 2007.

MACDONALD, I.M.; SAUVÉ, Y.; SIEVING, P.A. Preventing blindness in retinal disease: ciliary neurotrophic factor intra-ocular implants. Can. J. Ophthalmol., v.42, p.399402, 2007.
MARTIN, D.F.; PARKS, D.J.; MELLOW, S.D.; FERRIS, F.L.; WALTON, R.C.; REMALEY, N.A.; CHEW, E.Y.; ASHTON, P.; DAVIS, M.D.; NUSSENBLATT, R.B. Treatment of cytomegalovirus retinitis with an intra-ocular sustained-release ganciclovir implant. A randomized controlled clinical trial. Arch. Ophthalmol., v.112, p.15311539, 1994.

MOTTA, M.M.S.; COBLENTZ, J.; MELO, L.G.N. Aspectos atuais na fisiopatologia do edema macular diabético. Rev. Bras. Oftalmol., v.7, p.45-49, 2008.

NAIR, L.S.; LAURENCIN, C.T. Biodegradable polymers as biomaterials. Prog. Polym. Sci., v.32, p.762-798, 2007.

OKABE, J.; KIMURA, H.; KUNOU, N.; OKABE, K.; KATO, A.; OGURA, Y. Biodegradable intrascleral implant for sustained intra-ocular delivery of betamethasone phosphate. Invest. Ophthalmol. Vis. Sci., v.44, p.740-744, 2003.

PEYMAN, G.A.; GANIBAN, G.J. Delivery systems for intraocular routes. Adv. Drug Deliv. Rev., v.16, p.107-123, 2006.

RUBSAMEN, P.E.; DAVIS, P.A.; HERNANDEZ, E.; O'GRADY, G.E.; COUSINS, S.W. Prevention of experimental proliferative vitreoretinopathy with a biodegradable intravitreal implant for the sustained release of fluorouracil. Arch. Ophthalmol., v.112, p.407-413, 1994.

SANBORN, G.E.; ANAND, R.; TORTI, R.E.; NIGHTINGALE, S.D.; CAL, S.X.; YATES, B.; ASHTON, P.; SMITH, T. Sustained-release ganciclovir therapy for treatment of cytomegalovirus retinitis. Use of an intravitreal device. Arch Ophthalmol., v.110, p.188-195, 1992.

SEAH, S.K.L.; HUSAIN, R.; GAZZARD, G.; LIM, M.C.C.; HOH, S-T.; OEN, F.T.S.; AUNG, T. Use of Surodex in phacotrabeculectomy surgery. Am. J. Ophthalmol., v.139, p.927-928, 2005.

SILVA-CUNHA, A.; FIALHO, S.L.; NAUD, M-C.; BEHARCOHEN, F. Poly- $\varepsilon$-caprolactone intravitreous devices: An in vivo study. Invest. Ophthalmol. Vis. Sci., v.50, p.2312$2318,2009$.

SIQUEIRA, R.C.; RIBEIRO, E.F.; FIALHO, S.L.; LUCENA, L.R.; MAIA-FILHO, A.; HADDAD, A.; JORGE, R.; SCOTT, I.U.; SILVA-CUNHA, A. Pharmacokinetic and toxicity investigations of a new intraocular lens with a dexamethasone drug delivery system (IOL-DDS): a pilot study. Ophthalmologica, v.220, p.338-342, 2006. 
SMITH, T.J.; PEARSON, P.A.; BLANDFORD, D.L.; BROWN, J.D.; GOINS, K.A.; HOLLINS, E.T.; SCHMEISSER, E.T.; GLAVINOS, P.; BALDWIN, L.B.; ASHTON, P. Intravitreal sustained-release ganciclovir. Arch. Ophthalmol., v.110, p.255-258, 1992.

TAN, D.T.H.; CHEE, S.; LIM, L.; LIM, A.S. Randomized clinical trial of a new dexamethasone delivery system (Surodex) for treatment of postcataract surgery inflammation. Ophthalmology, v.106, p.223-231, 1999.

WADOOD, A.C.; ARMBRECHT, A.M.; ASPINALL, P.A.; DHILLON, B. Safety and efficacy of a dexamethasone anterior segment drug delivery system in patients after phacoemulsification. J. Cataract Refract. Surg., v.30, p.761-768, 2004.

YASUKAWA, T.; KIMURA, H.; TABATA, Y.; MIYAMOTO, H.; HONDA, Y.; OGURA, Y. Sustained release of cis-hydroxyproline in the treatment of experimental proliferative vitreoretinopathy in rabbits. Graefes Arch. Clin. Exp. Ophthalmol., v.240, p.672-678, 2002.
YASUKAWA, T.; OGURA, Y.; SAKURAI, E.; TABATA, Y.; KIMURA, H. Intraocular sustained drug delivery using implantable polymeric devices. Adv. Drug Deliv. Rev., v.57, p.2033-2046, 2005

YASUKAWA, T.; OGURA, Y.; TABATA, Y.; KIMURA, H.; WIEDEMANN, P.; HONDA, Y. Drug delivery systems for vitreoretinal diseases. Prog. Retin. Eye Res., v.23, p.253$281,2004$.

ZHOU, T.; LEWIS, H.; FOSTER, R.E.; SCHWENDEMAN, S.P. Development of a multiple-drug delivery implant for intraocular management of proliferative vitreoretinopathy. J. Control. Release, v.55, p.281-295, 1998.

Received for publication on $25^{\text {th }}$ June 2009 Accepted for publication on $20^{\text {th }}$ January 2010 